\title{
Between Order and Chaos: Lists in Children's Literature
}

Agnes Blümer

Cornflakes

Milk

Crisps

Pasta

Canned Tomatoes

Knitting needles

Yarn (Steinkellner 2015, 133) ${ }^{1}$

Lists are a very common but not yet widely researched phenomenon in children's literature. ${ }^{2}$ This chapter will investigate their verbal and visual forms, their function, and processes of knowledge construction and aims to contribute toward a poetics of the list in children's literature. The typical features of lists seem to parallel some of the characteristics of children's literature itself, and this might be the reason why they are a recurrent technique in texts addressed to children and young adults. ${ }^{3}$ Similar to the

\footnotetext{
A. Blümer $(\bowtie)$ University of Cologne, Center for Children's and Young-Adult Media Research (ALEKI), Köln, Germany e-mail: agnes.bluemer@uni-koeln.de

(C) The Author(s) 2022

R. A. Barton et al. (eds.), Forms of List-Making: Epistemic, Literary, and Visual Enumeration, https://doi.org/10.1007/978-3-030-76970-3_11
} 
perception of children's literature as a whole, lists in children's literature may be perceived as solely or mostly pedagogical in their function. This chapter intends to show that this didactic function is very important even as it acknowledges that many lists for younger readers are also intended to serve as a source of enjoyment through their reliance on rhymes, sounds, and their typical creative play with language. The didactic function is also subverted in many lists (especially in texts for older children): many lists do not transfer knowledge or moral standards but play with concepts of narration.

Lists can be found in different genres of children's literature: in children's poetry and children's folklore, in picture books and in novels for children as well as in novels for young adults. ${ }^{4}$ At a first glance, lists seem to work quite differently in the various genres. Yet, some unifying patterns may be identified. To be able to look at the various genres and forms of lists in the vast field of children's literature, a narrow definition of the list would not be useful. Thus, I will rely on the fact that we know a list when we see one. We can also turn to children's folklore and to nursery rhymes to find pointers for the nature of the list:

\author{
One's none, \\ Two' some, \\ Three's many, \\ Four's a penny, \\ Five's a little hundred. (Opie and Opie 1963, 164)
}

Apart from specific - and inevitably random-numbers of items, this example provides us with many other characteristics to be considered when defining a list: stylistic features like the parallelisms in the list above may play a role, the vertical layout seems to be important (although not mandatory), and other typographic features (like the line breaks, the commas, and the colon above) contribute to the list-like quality. Also, materiality and modality, the oral traditions, mnemotechnic, and rhetoric play a role when defining lists, and one would also have to talk about seriality and episodic structure, as well as the differentiation of lists and enumerations. Robert Belknap's $(2004,2)$ definition might be the most useful here: "At their most simple, lists are frameworks that hold separate and disparate items together. Lists are plastic, flexible structures in which an array of constituent units coheres through specific relations generated by specific forces of attraction." 
Starting from this broad definition, the initial focus of this contribution will be on the content of lists in children's literature: which items are listed? If we look across the various genres of children's literature, the lists often contain children's treasures and belongings like toys or sweets or curious finds, elements of their everyday world, or names of characters and animals who play an important role in the child's imagination-perhaps, for example, in the form of fantastical world building. Lists in children's literature may of course be of a more paratextual nature and consist of names or places that play a key role in the text. Especially striking in their number are lists that are sets of defined and distinct objects or concepts such as the days of the week, the months of the year, the letters of the alphabet, or the parts of the human body. Obviously, the content of these lists is meant as a kind of curriculum that children are supposed to learn.

\section{Lists ARE FOR LEARNING}

Head, shoulders, knees and toes, Knees and toes.

Head, shoulders, knees and toes, Knees and toes.

And eyes and ears and mouth and nose.

Head, shoulders, knees and toes,

Knees and toes. (https://allnurseryrhymes.com/head-shoulders-kneesand-toes/)

This nursery rhyme may serve as an example for the kind of "curricular lists" mentioned above; when performed with the accompanying gestures (pointing to the body parts in question in a kind of dance) it is meant to help toddlers or small children remember the names of parts of the body. This seems to be the first function of lists: lists in children's literature have educational purpose, they are didactic.

In its repetitions ("knees and toes"), rhymes ("toes" / "nose"), catchy quality, and structure, this list is also a perfect example for the simplicity of a list. Lists work on an enumerative principle; therefore, they are a relatively "simple" form. ${ }^{5}$ Their apparent simplicity of course lends itself well to pedagogical use. In her article on lists in British children's poetry, Debbie Pullinger connects lists' apparent simplicity with the typical young audience, seemingly performing a well-established move in children's literature research (if it is simple, it is for children): "If the list can be seen as a relatively simple poetic form, then we might conjecture that children's 
poets feel instinctively that it offers easy listening for unsophisticated ears" (Pullinger 2015, 208; Pullinger will modify this view very plausibly later in her article). This is a first parallel between the list and children's literature: their apparent simplicity. As simple forms, not only do they offer a highly accessible means of auditory engagement but also lend themselves aptly to the well-arranged and memory-friendly presentation of reality. Knowledge is broken down into items in an enumeration, no complex explanations are needed, and all the items are or seem equally accessible. With their enumerative structure, lists organize and allow to transfer knowledge without further explanation.

Maybe these simple nursery rhymes show the lists' origins in oral traditions the most clearly. Lists can be seen, as Pullinger writes, as an "outworking of oral culture's additive dynamic" (Pullinger 2015, 209). In nursery rhymes and children's poetry, memorable patterns like rhythm and rhymes but also actions which are performed with the words facilitate the learning of various things; list items that rhyme will (probably) be remembered more easily. Many poems structured according to defined and often finite sets of items seem to rely on this principle.

\section{Lists as Aesthetic Experiences}

Lists are certainly suited for educational use in their simplicity and matterof-factness, but their affinity toward repetitions, their rhythm, their sound, and their rhymes also offer early exposure to certain literary qualities and, indeed, to literature itself-perhaps a first inkling of what Umberto Eco calls the "dizzying sound of the list" $(2009,118)$. This is the second intent of lists in children's literature: in their simple form, they offer children access to literature at a very young age. ${ }^{6}$ The function of offering early literacy experiences may go hand in hand with the didactic function (as in "Heads, Shoulders, Knees and Toes"), but it may in some instances even subvert the first, the didactic function. Lists in poetry can often verge on nonsense and end up in intoxicating absurdity, as many list poems for children show. One example would be "Too many Daves" by Dr. Seuss, taken from The Sneetches and Other Stories (1961), a catalogue of 23 nonsensical and funny names:

Too many Daves

Did I ever tell you that Mrs. McCave

Had twenty-three sons and she named them all Dave? [...] 
And often she wishes that, when they were born, She had named one of them Bodkin Van Horn. And one of them Hoos-Foos. And one of them Snimm. And one of them Hot-Shot. And one Sunny Jim. And one of them Shadrack. And one of them Blinkey. And one of them Stuffy. And one of them Stinkey. Another one Putt-Putt. Another one Moon Face. Another one Marvin O'Gravel Balloon Face. And one of them Ziggy. And one Soggy Muff. One Buffalo Bill. And one Biffalo Buff. And one of them Sneepy. And one Weepy Weed. And one Paris Garters. And one Harris Tweed. And one of them Sir Michael Carmichael Zutt And one of them Oliver Boliver Butt And one of them Zanzibar Buck-Buck McFate. But she didn't do it. And now it's too late.

If a list can be this crazy, can it also be educational? Apart from the fact that children can use this list to count to 23 , there seems to be little educational value in this list in that it does not transfer any factual knowledge. But as a list of (male) names with reference to the characters' decents and the inclusion of "fate," this certainly reads as a parody of epic catalogues (an intertextual reference addressed to the experienced reader). To young readers it may convey a sense of the possibilities of literature as it uses some of its more striking features: telling names (all of the names can be interpreted as displaying some rather funny features of the character in question), play with sounds (most of the names seem to be built on comical sound effects), word play (e.g., Biffalo Buff), intertextual references (Shadrack/Shadrach as biblical figure), and other rather obscure references (Paris Garters). The anapaestic tetrameter and rhyming couplets seem to accelerate the text when read aloud, contributing to the sense of escalation one feels when reading or hearing this poem. ${ }^{7}$ The last verse ("But she didn't do it. And now it's too late") seems to provide a closure to this list, to contain it-but paradoxically, it does not succeed: Mrs. McCave may not have named her sons differently, but this list just did. Such tendency for excess, for puns, and for comical effects seems to undermine the traditional educational value of the list form, although it may absolutely function as an experience of early literacy, an encounter with elements typically associated with literary style-albeit a little distorted for fun. 
The effect of reading the poem aloud points to another peculiarity of lists for children: they are often meant to be read in shared, communal, or communicative reading settings when an adult reads to one or more children or adult and child share reading "duties." Most texts for children cater to a dual or double addressee (see Barbara Wall 1991 for this distinction) and include elements addressed to young readers, others probably only to be understood by older (or more experienced) readers. Here the comical sound effects seem to benefit the young, while the intertextual and fashion references (Paris Garters, Harris Tweed) may rather be detected by the adult reader.

\section{Lists As INTERACTIVE EXPERIENCES}

Another function of lists becomes obvious here, apart from their educational value and their potential for first literary experiences. Their additive form suggests abundance, multitude, sometimes even infinity. Although the list of Daves is finite-there are only 23 of them-lists in children's literature often play with the infinite. This function of lists (referencing high numbers or big amounts of items or even alluding to infinity) is not reserved to children's literature, but here it may sometimes be used in a peculiar way: lists can be an invitation for interaction, especially when read aloud. When looking at the list by Dr. Seuss, almost any child can add or swap a crazy name to the list of Daves. Adults reading rhyming lists to children aloud will often leave gaps or stop before the end of the verse to let children fill in the next item which will complete the rhyme.

This invitation for interaction is explicit in a prompt for creative writing in Brian P. Cleary's Underneath My Bed. List Poems, when he first explains the structure of list poems and then suggests to young readers: "Now, don't make a list of excuses - get busy writing!" (Cleary 2017, 5) Here, the interaction is not restricted to oral situations but continues into the written form as children are encouraged to write their own lists. That this seems reasonably plausible might not only have to do with rhyming patterns of lists in poetry but also with the organization of lists. Due to their additive structure lists seem easily accessible and also easily writable. In this way, lists can be a tool for blurring the boundaries between reader and creator.

To conclude this overview of lists in poetry for children, it is also important to note that poetry in general seems to lend itself well to lists because the verse form resembles a vertical list with several items written 
underneath each other. The axes of paradigmatic relations are strong both in lists as well as in poetry. Relating to British children's poems, Pullinger estimates that "approximately ten per cent of the poems could be identified as employing list form - whether as a simple series of items, an elaborated series, or enclosed within a larger structure" $(2015,208)$. Contemporary German language children's anthologies are also full of list poems (approximately 20 percent of the poems in recent anthologies may be categorized as lists), often nonsensical ones. Current children's poets like Arne Rautenberg, Uwe Michael-Gutzschahn, Elisabeth Steinkellner, and Susan Kreller seem to appreciate the list's ability to combine the everyday, the poetical, and the comical in rather accessible texts for children.

Not only lists in children's poetry but whole genres in children's literature and folklore use an interactive principle. Cumulative tales and songs like "This is the House that Jack built" or "There was an Old Lady That Swallowed a Fly" can be read as lists. They are certainly made for shared reading experiences and in their predictability give the child an opportunity to chime in and to fill in words or verses.

\section{Lists as Archives of Voracity}

This invitation or even provocation to interact makes the list a playful form. Sabine Mainberger sees lists as "enumerative games" (my translation of Mainberger 2003, 7). This is another shared characteristic of the list form and children's literature: the importance of play and the possibilities for interaction. The child's desire for continuation may play a role here. Umberto Eco writes on the "insatiable" list: "But in traditional rhetoric there is no interesting definition of what strikes us as the dizzying voraciousness of the list" $(2009,137)$.

This "voracity" may find a counterpart in the child's desire for more when the joy of copiousness is expressed in the literary list. One expression of such desire can be found in wish lists in children's literature, where two kinds of voracity are brought together: one on the material and one on the auditory level. Wish lists can be spotted in any genre and sometimes in their exaggerated form make up an entire poem like Barbara Vance's poem "Dear Santa." In this proleptic catalogue, a little child lists their wishes in a very long stanza addressing Santa:

So I've made up a list to assist you With the hope that it's perfectly clear: 
One princess ballerina doll (the one with curly hair), A pair of skates, a pogo stick, one fuzzy teddy bear; A pink snow cap with matching gloves, a puppy in a box, A stocking with my favorite sweets, a brand new set of blocks; I want another china doll (I dropped the one I had; I tried to make her better, but the injury was bad). A set of drums, a big doll house, a new bell for my bike, The sweater that my best friend has (so we can look alike); A great big pack of bubble gum (I chew it every day), A radio, a telescope, a massive wad of clay. [...] (2020)

Obviously, here, the literary list mimics the child's writing, but it also becomes a fictional archive of the child's everyday life, hopes, and dreams. Wish lists may be an interesting genre to look at historically: how do the toys listed change and how is the child's world reflected in the list? The list here becomes an archive in the sense in which Moritz Baßler (2002) describes pop literature and its archival merit ("Archivierungsleistung," Baßler 2002, 21). Mundane items which normally would not be included in "serious" literature are included in the archive of the text and thus in our cultural memory. ${ }^{8}$

Also, Joosen and Pauwels (2018) find that "wish lists gear the young for consumerism and even greed, as they instill in children a desire for ever more commodities" (56). A kind of greediness is certainly apparent when the wish list poem, like the nonsensical list poem, seems to escalate quickly as more and more wishes are added (the text above is just an excerpt from a much longer poem). Some wish lists even seem to lack any reality in the sheer number of wishes listed. Children's literature certainly seems to abound with wish lists detailing children's longings and dreams. Not each specific object of desire seems important, but desire itself is often the topic of these escalating lists. Desire in children's literature has been seen as a necessary step toward autonomy (and toward adolescence and adulthood). Karen Coats in her psychoanalytic reading sees children's books as parameters of desire: "the child (unconsciously) uses his books [...] to fill his unconscious with representations and images, shape his reality, and define the parameters of his possibilities. [...] [T] his process depends on repetition-both the repetition of the same book, and the repetition of structures, images, and values across books. Hence, as her books have a definable structure, so structure becomes a psychic necessity for the child. 
As her books depict a whole world, the child seeks nothing less than a whole world" (Coats 2004, 6-7). As she shows here, structure, repetition, and fullness (arguably all features of the list) play an important role in shaping the child's identity, and lists seem to play an important part in offering an almost fantastical glimpse into that desirable adult world.

The playfulness of lists, their tendency to veer toward the fantastical, nonsensical, or absurd, and their function as archives of voracity seem to be important factors when we consider their attractiveness for the intended audience. Although simplicity and accessibility are certainly some of the reasons why lists are used in children's literature, and while they are often used with educational purposes in mind, they are more than didactic tools. ${ }^{9}$ There is another feature of children's lists that might make them attractive for their intended audience: they often combine two codes, the verbal and the visual so that advanced reading skills are not absolutely necessary to access the list.

\section{Visual Lists in Picturebooks}

Whereas wish list poems can be read as catalogues of desire, the picturebook famously uses the list as catalogue of the whole world. Picturebook lists may rely on solely visual elements or they may combine two codes: word and image. They differ in this from lists in a narrower sense, and according to Umberto Eco, we might classify them as "visual lists" (Eco 2009, 36-38). Orbis sensualium pictus by Amos Comenius (1653), the publication that is widely regarded as one of the first picturebooks, is essentially a list of Latin words describing the whole world. It presents, among many other topics, for example "olera," garden vegetables (picture taken from a later quadrilingual edition, 1760) (Fig. 11.1):

Under the picture of a vegetable garden, which can be read as a visual list of the vegetables in question, we find a vertical verbal list in three columns giving the names of the vegetables in Latin and German, as well as grammatical information. Both the picture as well as the words are numbered so the reader can find the correct names for the elements in the picture in the written legend (e.g., I is lactuca, Salat-lettuce). Although the verbal and the visual list here seem quite separate, they are intertwined in their equivalences and through these numbers. Clearly, the educational function is to teach the names of vegetables in different languages, and the visual cues supplement the verbal ones. 


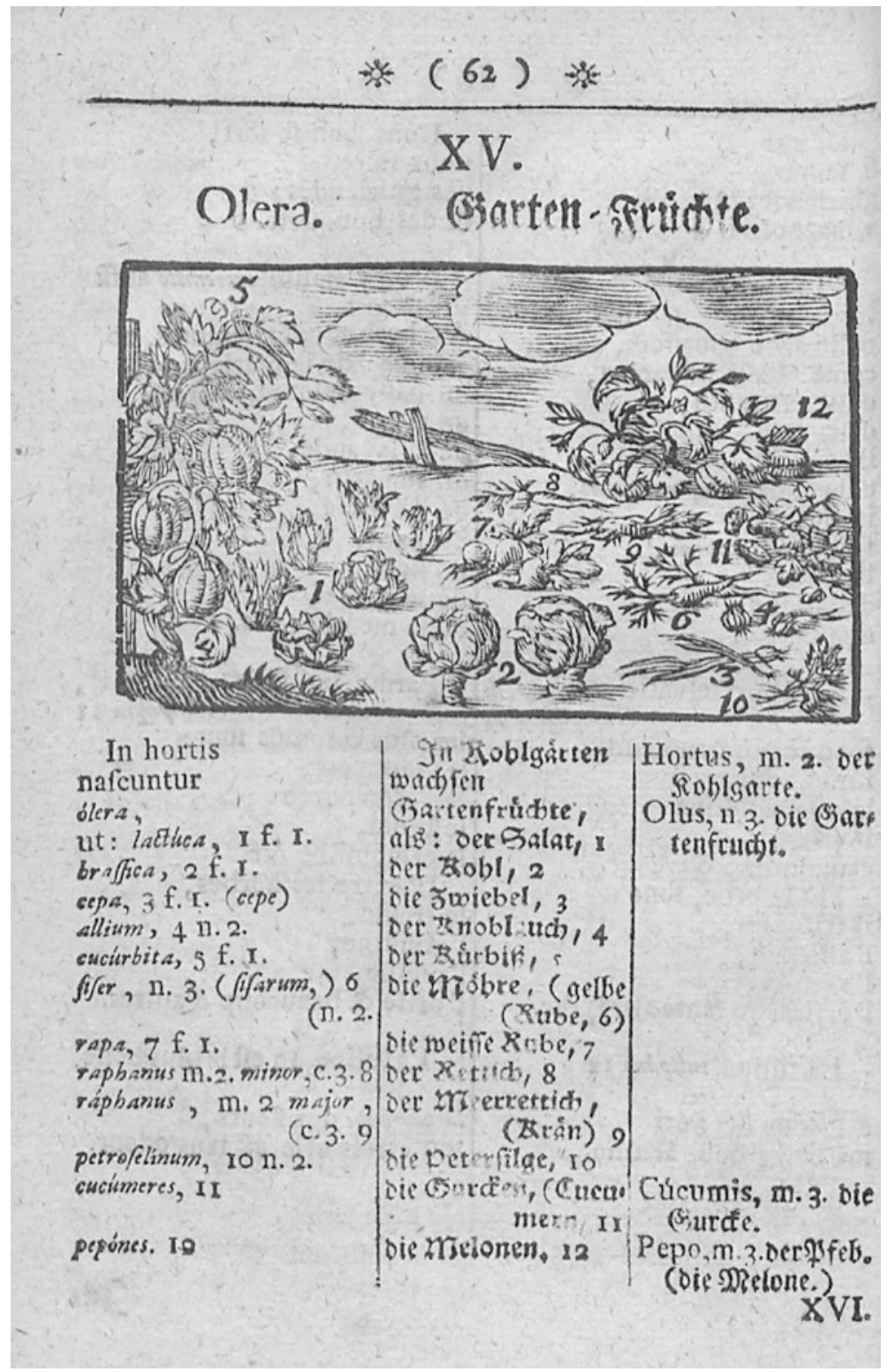

Fig. 11.1 Olera. Garten-Früchte, in John Amos Comenius, Orbis sensualium pictus (Nuremberg 1760), 62 


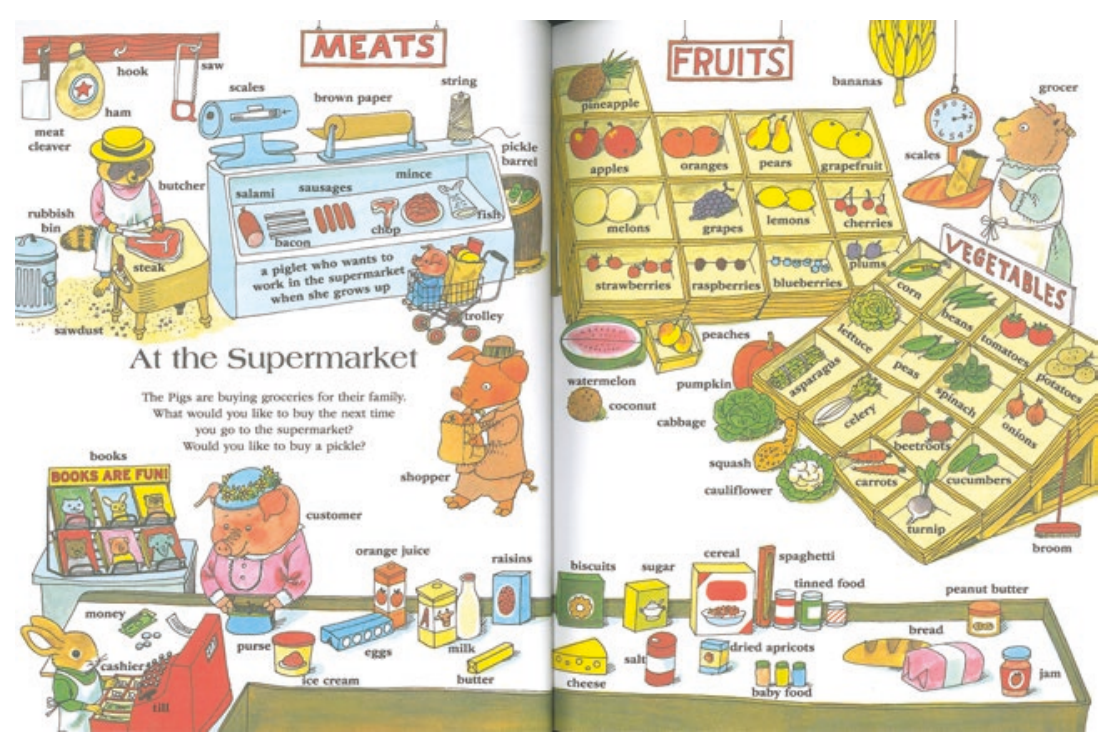

Fig. 11.2 At the Supermarket, in Richard Scarry, Best Word Book Ever (1991), n.p.

To this day, early literacy picture books and word board books are structured in a similar fashion as lists and present knowledge to be acquired and words to be learned. Again, the use of lists here stems from an educational impulse. Like in the precursor Orbis pictus these lists may combine the two codes: verbal and visual. These lists, too, seem to suggest copiousness, like for example Richard Scarry's "At the Supermarket," taken from his famous Best Word Book Ever, first published in 1963 and again in 1980 with new illustrations (picture taken from the 1991 edition, no page numbers) (Fig. 11.2):

In the supermarket spread, especially on the right side of the double page, we can still see a pretty close connection to the vegetable list in Orbis pictus three centuries before. The layout in Scarry's book is different; there is no vertical list and the visual and the verbal lists are not separate like in Orbis Pictus but rather intertwined: the verbal list is written into the picture as little tags underneath the items in question. Still, both Scarry's and Comenius' verbal/visual list may be read as attempts to archive the everyday and also to convey the yet unknown to the child. Both examples invite the reader to interact with the list in its two codes: to learn the words, to point to the items, and to name them. 
Both lists also hint at narration. Comenius prefaces the vertical list with an opening sentence ("In hortis nascuntur olera," "Vegetables are growing in the garden") like a narration, and Scarry hides snippets of narration in his tags, for example, "a piglet who wants to work in the supermarket when she grows up" to "label" the little pig girl in the shopping trolley. Scarry's introductory sentence, like Comenius', also provides a narrative context ("The Pigs are buying groceries for their family"), and the next two sentences amplify the invitation for interaction. They provide the (probably) adult reader with questions to ask the (probably) child addressee: "What would you like to buy the next time you go to the supermarket?" Like some wish lists, this question seems tied to the intent to educate the child to become a "good" client or consumer or to maybe spark a conversation about food choices.

For children's literature, it is important to note that both verbal and visual lists may be pedagogical when they serve as instruction or memory aids for learning, but both kinds can also be playful and focus on conveying sensations or offering early literary experiences. Obviously, in modern word books, lists are used to present aspects of reality in a structured way to little children, as when the supermarket items, for example, are sorted into the categories "meats," "fruits," and "vegetables." Verbal and visual lists act as catalogues of knowledge or possessions, but they are aesthetical fabrications, too, in that their pictures serve as an experience of art, color symbolism, and picture composition.

Visual lists can be found in many narrative picture books as well, as for example in Eric Carle's The Very Hungry Caterpillar where, again, we find lists focused on food-in this case, the caterpillar eating its way through a true inventory of (human) food. Its eating journey is narrated in doublepage spreads (and the famous smaller part-pages with holes) that correspond to the days of the week (e.g., "On Monday he ate through one apple. But he was still hungry") and culminate in Saturday's menu: "On Saturday he ate through one piece of chocolate cake, one ice-cream cone, one pickle, one slice of swiss cheese, one slice of salami, one lollipop, one piece of cherry pie, one sausage, one cupcake, and one slice of watermelon. That night he had a stomachache!" (Carle 1994, no page numbers). Of course, the story may serve as learning material for the days of the week (a finite set so appropriate for a finite list) and the numbers, but the most memorable experience is probably a visual and tactile one: of touching the thick pages with their holes, of taking in Carle's collages with various textures and colors, and of reveling in the indulgent food choices. 
Again, we see the list as a multipurpose form here: it seems to be educational, aesthetical, and interactive.

A huge number of narrative picture books for very young children are essentially lists. Simple sentences or structures are listed, repeated, and modified, as in Molly Bang's Ten, Nine, Eight (first published in 1983) or Margaret Wise Brown's Goodnight Moon (first published in 1947), where everything in the room is listed and bid goodnight: "Goodnight room Goodnight moon - Goodnight cow jumping over the moon" (Brown 2017 , no page numbers). Every element of the list is present both in verbal as well as in pictorial form. Stating and repeating the items is a routine process likely to offer reassurance to the child by summarizing and archiving the world that surrounds them. Again, this list prompts interaction: caregivers and children are likely to list the elements in their own room and tell them goodnight after reading this book. The parallelisms and repetitions of this process lead to a certain monotony which helps to calm the child and perhaps even lull it to sleep. Apart from these verbalvisual lists, there are also wordless picture books which can be read as lists. Those for very early literacy present one item per page to be named in reading situations with a caregiver ("duck," "ball," ...). They, of course, are a prime example of the educational nature lists may have in children's literature when, again, in an interactive reading setting, children may learn the words to match the items shown.

\section{Lists as Reading Promotion}

Lists in novels for young readers may have pedagogical function, too. While these texts mostly move away from presenting items to be learned, lists seem to be used here with a different aim in mind: to promote literacy and to encourage independent reading. Lists can structure longer texts and make them more easily accessible and a quicker read. As Joosen and Pauwels (2018) put it: "From a developing reader's perspective, lists reduce the time spent on reading, without reducing the overall achievement of finishing a book." This is certainly the case for Kristin Mahoney's Annie's Life in Lists (2018). The novel consists only of lists but still unfolds the plot of Annie who loves making lists to help her keep track of things that seem a little out of control such as when her family moves from Brooklyn to a small town, Clover Gap. A review from the School Library Journal reveals what I suspect to be one aim of lists in novels for younger readers. Liz Anderson (2018) writes: "Even with its imperfections, the 
format, featuring illustrations throughout, will make it a great choice for reluctant readers." Lists can make longer texts more bite-sized for beginning or reluctant readers; the lists break up the continuous text and offer little breaks in between. The novel is also a very good example of how fictional child characters use lists as "coping mechanisms" (Joosen and Pauwels 2018, 53). The blurb on the front dust cover of this list novel reads: "Welcome to a year in the life of a kid just trying to keep everything in order" (Mahoney 2018). Annie is trying to make sense of her new surroundings and clings to the familiarity and order of lists when she chronicles her life after the move.

\section{Lists AND CONFUSION}

So far, in mentioning poems, picture books, and Annie's Life in Lists, this chapter has dealt mostly with texts that consist of one list or several lists, that is: texts that are lists. But of course, one can also find lists that constitute parts of novels, where continuous text is interspersed with lists. Lists might also, by providing the title and the chapter headings as list items, structure a novel or a narrative that is mainly continuous text. ${ }^{10}$ In Why We Broke Up (Handler and Kalman 2011) the list structure stems from objects and images in a box that the female protagonist Min dumps at Ed's front door after they have broken up. "This is the box, Ed. Inside is everything." In the blurb, this announcement is followed by a list of some of these objects:

Two bottle caps, a movie ticket from Greta in the Wild, a note from you, a box of matches, your protractor, Joan's book, the stolen sugar, a toy truck, those ugly earrings, a comb from the motel. and the rest of it.

This is it, Ed.

The whole story of why we broke up. (Handler and Kalman 2011, back cover) 
In the book, every chapter is dedicated to one of the items and each chapter is headed by an illustration by Maira Kalman. As Min says or rather writes in a long letter, the items make up a catalogue or archive of artefacts of their past relationship that lasted only a few weeks: "Every last souvenir of the love we had, the prizes and the debris of this relationship, like the glitter in the gutter when the parade has passed, all the everything and whatnot kicked to the curb. I'm dumping the whole box back into your life, Ed, every item of you and me" (Handler and Kalman 2011, 3). Here, the whole book becomes an inventory which is even more tangible because of the illustrations dividing the text into chapters and showing every single item. But this list is not an objective one: it is clearly Min's view of why they broke up, and the seemingly material objectivity of the list is undermined by several literary techniques, for example by elaborate pop culture references that lead absolutely nowhere. As Monica Edinger noted in The New York Times' Sunday Book Review: "Handler has made them all up, but so superbly you feel certain they must really exist" (Dec 16, 2011). As we can see here, lists in children's literature do not only provide structure and order; they can also be misleading like this list of verbal and visual references to movies, bands, songs, and books that the reader feels they must know. But if the reader, maybe confused or ashamed of their ignorance, tries to research some of the art that is described and shown in great and intricate detail, it is revealed that none of it exists.

Lists in literature for young adults often represents confusion and disorientation; they can break up the former coherence of the narration. Eva von Contzen (2017, 226, trans. by Nathan Anderson) has shown this already when talking about literary texts for adults: "When narratives employ enumeration, they initially break up the narrative coherence: that which binds them together as narratives grows feeble and inert." ${ }^{\prime l}$ This is what happens here as well, and of course it is significant that we do not find this so much in texts for small children but rather in young adult fiction or adolescence novels. Here, the pedagogical impulse may take a back seat, and also the fragility and changes represented by list structures are the very themes of the adolescence novel.

In Elisabeth Steinkellner's novel Rabensommer (published in 2015, not translated into English, the title would translate as Summer of Ravens) we get an impression of the protagonist's insecurity through her lists. It is the summer after Juli's matura, the Austrian capstone examination before graduation. When her life threatens to spiral out of control in the second part of the book, the cohesive text dissolves into lists, dreams, text 
messages, and short episodes. This is when her friend August writes a meta-list to and about Juli on a postcard:

what I like about Juli:

that she starts to write lists in times of crisis

that it makes her happy to drink vanilla tea from flowered grandmother's cups

that $[\ldots]$

that she will be gnawing at her lip when she reads this. (Steinkellner $2015,192)^{12}$

Like in Why We Broke Up, lists are explicitly linked to crisis here, and the crisis is triggered by Niels, who breaks up with Juli, but it is also fueled by the sense of betrayal Juli feels toward her two other friends, August and Ronja, for having sex together. Both events are narrated at the end of the first part of the novel which consists of conventional continuous text. However, the opening pages of the second part show how much Juli feels thrown offtrack by these events, the first page simply reading:

Bread

Butter

Milk

Coffee (Steinkellner 2015, 97) $)^{13}$

Narration does not seem possible anymore; we get only fragments of a shopping list that seems to function as a kind of foothold, or again, a coping mechanism, for Juli. The following pages hold more pragmatic lists, many of them shopping lists.

These lists are symbols of the teenage protagonist's desperate search for stability and orientation; they are symptoms of her disorientation and helplessness. It seems that this loss of sense and orientation is represented in the fragmentation of the text, in the groping for stability — and although this is certainly true to a certain extent, it is also deceptive: lists cannot be equated with chaos here. They do not (necessarily) stop the narrative flow. When we read, for example, the shopping lists carefully, we realize they are actually foreshadowing plot elements that are narrated later. Readers can guess developments before they are narrated-or even without them being narrated in continuous text at all. For example, shopping lists hint at menus (a lentil dhal with a side of bread and butter?) and new relationships (where toothpaste and condoms seem in order): 
Bread

Butter

Avocado

Cucumber

Lemon

Coconut milk

Lentils

Wine

Toothpaste

Condoms (Steinkellner 2015, 171) $)^{14}$

These lists rely on the participation of the reader, because in reading (as Eva von Contzen wrote, my translation) "the reader makes these building blocks into a narration, when before they have only been the scaffolding for a potential narration." "The reader builds a menu from the grocery items and notes that these groceries, unlike before, actually seem to add up to a nice meal, one for which Juli might have company over. "Toothpaste" is another sign that the young man she has fallen in love with might be the dinner companion, and the last item, "condoms," seems to confirm this. Lists as symbols of fragmentation and helplessness redirect into storylines with the readers' help. Again, lists seem to invite the reader to interact, to take part in them, to make sense of them.

\section{Conclusion}

Lists in children's literature offer structure: lists can be scaffoldings for narratives or for world building, they can represent and teach reality, they can offer reassurance, and they can make longer texts more accessible. The perceived simplicity of lists allows us to try to grasp the ineffable or infinity. Lists are clearly used for didactic purposes, and this is probably an explanation for the abundance of lists in children's literature. The list seems to offer up the characteristics of children's literature as if placed under a magnifying glass: didactic, playful, interactive, visual, and aesthetic elements become especially apparent.

Debbie Pullinger once more highlights the list's affordance to textually archive a lost world when she suggests that "since all children's literature is concerned with the eventual 'death' of the child in order to become an adult, both the elegy and the list are at the heart of children's literature" (Pullinger 2015, 214). But the list is not only an orderly archive for the 
child's fleeting life; the disintegration of a text into lists can also imitate the feeling of chaos. Lists can escalate quickly; they can be nonsensical or absurd to an extreme.

Lists seem to vacillate between the extremes, between simplicity and complexity, between order and chaos, between the didactic and the purely aesthetic. Evelien Neven $(2018,123)$ points out that "contrasts are inherently connected to the list form itself" and that lists can lean toward one or the other pole on a continuum. If we want to bring the two opposites together, I think we may view it like this: lists may convey the presence or the absence of order, depending on how we see it. Is a list a "failure," something that is not continuous text, or is it an achievement, the result of organizing various items?

At any rate, the list is an invitation: to learn, to play, to search, to name, to write, or to narrate. Depending on the genre, the reader's age and on each specific text, lists in children's literature can be more educational or more literary, but mostly they include both extremes in some form: they are orderly and chaotic, they are nonsensical and meaningful, they bring narrations to a halt, and they make them start again.

\section{Notes}

1. This is my translation. Steinkellner's book Rabensommer has not been translated into English yet. The original German text:

Cornflakes

Milch

Chips

Nudeln

Dosentomaten

Stricknadeln

Wolle (Steinkellner 2015, 133)

2. This has begun to change recently: the most important current articles on lists in children's literature are by Debbie Pullinger (2015) and Vanessa Joosen, and Frauke Pauwels (2018 but published in 2020). I did not know of the latter article at the time of writing this paper but was kindly made aware of it by the editors of this volume for my revision. Many points we are making are very similar, so I will point to Joosen and Pauwels where appropriate. 
3. Joosen and Pauwels $(2018,49)$ also see a parallel between children's literature and lists in the fact that they can both "make the strange familiar, and make the familiar strange." I believe this is similar to my understanding that lists can both convey order as well as chaos.

4. This article will orient itself along some of the genres of children's literature and move from poetry to folklore, picture books, novels for children, and lastly to young adults.

5. Eva von Contzen sees lists as an ambivalent form between complexity and simplicity: "ambivalente Form zwischen Komplexität und Einfachheit" (von Contzen 2017, 222).

6. Joosen and Pauwels $(2018,49)$ also see lists in the context of "becoming a reader."

7. Eco $(2009,118)$ describes similar effects when it comes to Catholic Litanies: "What matters is being seized by the dizzying sound of the list, just as in the Litanies of the Saints what matters is not so much which of them [the saints] is present or absent, as the rhythmic enunciation of the names for a sufficiently long period of time."

8. See Baßler's reading of Max Goldt's texts: "Wir kennen fast alles, was in Goldts Kolumnen zur Sprache kommt [...], aber gelesen hatten wir darüber noch nicht, es war bislang nicht Gegenstand jener künstlerischen Anstrengung gewesen, über die Dinge ins kulturelle Archiv gelangen. [...] Die Verfahren, die in der Pop-Literatur von Goldt und anderen am Werk sind, lassen sich genau als solche Mechanismen verstehen, die 'das Verhältnis zwischen dem valorisierten, hierarchisch aufgebauten kulturellen Gedächtnis einerseits und dem wertlosen profanen Raum andererseits regeln'. Das kulturelle Archiv, das dabei bestückt wird, ist das der Literatur" (Baßler 2002, 21). To be clear, Baßler is not necessarily talking about lists here, as his definition of lists is a typographical one, in which he sees line breaks as indispensable ("als Liste, also wie in Versdichtung mit Zeilenbrüchen untereinander notiert [...] statt als Fließtext," Baßler 2020, 184).

9. As Pullinger puts it: "the didactic impulse does not seem a wholly adequate explanation for the prevalence of the list" $(2015,2018)$ in children's literature.

10. Some examples for this technique published in the last ten years are: Thirteen Reasons Why (Jay Asher 2007; TV series as THIRTEEN R3ASONS WHY, 2017), 12 Things to Do Before You Crash and Burn (James Proimos 2011), Why We Broke Up (Daniel Handler and Maira Kalman 2011) 10 Things I Can See from Here (Carrie Mac 2017), The Bad Decisions Playlist (Michael Rubens 2016), or 36 Questions That Changed My Mind About You (Vicky Grant 2017). 
11. Original text: "Wenn Erzählungen sich des Enumerativen bedienen, brechen sie zunächst narrative Kohärenz auf: Das, was sie als Erzählungen zusammenhält, wird brüchig, außer Kraft gesetzt" (von Contzen 2017, 226).

12. Original text:

was ich an Juli mag:

dass sie in Krisenzeiten beginnt, Listen zu schreiben

dass es sie glücklich macht, aus geblümten Omatassen Vanilletee zu trinken dass $[\ldots]$

dass sie an ihrer Unterlippe kauen wird, wenn sie diese Karte liest (Steinkellner 2015, 192).

13. Original text:

Brot

Butter

Milch

Kaffee (Steinkellner 2015, 97)

14. Original text:

Brot

Butter

Avocado

Gurke

Zitrone

Kokosmilch

Linsen

Wein

Zahnpasta

Kondome (Steinkellner 2015, 171)

15. Original text: "narrativiert der Leser die Bausteine dessen, was zunächst Gerüst einer potenziellen Erzählung ist" (von Contzen 2017, 234). 


\section{REFERENCES}

\section{Primary Sources}

Bang, Molly. 1996 [1983]. Ten, Nine, Eight. New York: HarperCollins.

Brown, Margaret Wise. 1947. Goodnight, Moon. Pictures by Clement Hurd. New York: HarperCollins.

Carle, Eric. 1994 [1969]. The Very Hungry Caterpillar. London: Puffin.

Cleary, Brian P. 2017. Poetry Adventures. Underneath My Bed. List Poems. Illustrations by Richard Watson. Minneapolis: Millbrook Press.

Comenius, Johann Amos. 1760. Joh. Amos Comenii Orbis Sensualium Pictus Quadrilinguis Emendatus, Hoc est: Omnium fundamentalium in mundo Rerum, \& vita Actionum, Pictura \& Nomenclatura, [...]. Noribergx: Endter.

Dr. Seuss. 1961, 1989. The Sneetches and Other Stories. London: HarperCollins.

Handler, Daniel. 2011. Why We Broke Up. Illustrations by Maira Kalman. New York: Hachette.

Heads, Shoulders, Knees, and Toes. Nursery Rhymes. https://allnurseryrhymes. com/head-shoulders-knees-and-toes/. Accessed 26 Mar 2020.

Mahoney, Kristin. 2018. Annie's Life in Lists. New York: Knopf.

Opie, Iona, and Peter Opie. 1963. The Puffin Book of Nursery Rhymes. London: Penguin.

Scarry, Richard. 1963, 1991, 2013. Best Word Book Ever. London: HarperCollins. Steinkellner, Elisabeth. 2015. Rabensommer. Weinheim/Basel: Beltz und Gelberg. Vance, Barbara. 2020. Dear Santa. http://www.suziebitner.com/portfolio/dearsanta/. Accessed 8 Apr 2020.

\section{SECONDARY Sources}

Anderson, Liz. 2018. Annie's Life in Lists: Review. School Library Journal. https://www.schoollibraryjournal.com/?reviewDetail=annies-life-in-lists. Accessed 8 Apr 2020.

Baßler, Moritz. 2002. Der deutsche Pop-Roman: Die neuen Archivisten. München: C.H. Beck.

- 2020. Katalog- und Montageverfahren: Sammeln und Generieren. In Handbuch Literatur \& Pop, ed. Moritz Baßler and Eckhard Schumacher, 184-198. Berlin/Boston: De Gruyter.

Belknap, Robert E. 2004. The List: The Uses and Pleasures of Cataloguing. New Haven/London: Yale University Press.

Coats, Karen. 2004. Looking Glasses and Neverlands: Lacan, Desire, and Subjectivity in Children's Literature. Iowa City: University of Iowa Press.

Eco, Umberto. 2009. The Infinity of Lists: From Homer to Joyce. Trans. Alastair McEwen. London: MacLehose Press. 
Edinger, Monica. 2011. Daniel Handler's Teenagers Out of Love. The New York Times, December 16. https://www.nytimes.com/2011/12/18/books/ review/why-we-broke-up-by-daniel-handler-illustrated-by-maira-kalmanbook-review.html. Accessed 8 Apr 2020.

Joosen, Vanessa, and Frauke Pauwels. 2018. The Pleasures of Plenitude: Becoming a Reader Through Literary Lists. In lwu: Literatur in Wissenschaft und Unterricht. Theme Issue: Lists and Narrative, ed. Evelien Neven, Bart Vervaeck, and Luc Herman, 49-62.

Mainberger, Sabine. 2003. Die Kunst des Aufzählens: Elemente zu einer Poetik des Enumerativen. Berlin/New York: de Gruyter.

Neven, Evelien. 2018. "Kraai, Krähe, crow, corneille, corvus": On Reading Lists in Peeters' Great European Novel. In lwu: Literatur in Wissenschaft und Unterricht. Theme Issue: Lists and Narrative, ed. Evelien Neven, Bart Vervaeck, and Luc Herman, 123-137.

Pullinger, Debbie. 2015. Infinity and Beyond: The Poetic List in Children's Poetry. Children's Literature in Education 46 (3): 207-225.

von Contzen, Eva. 2017. Grenzfälle des Erzählens: Die Liste als einfache Form. In Komplexität und Einfachbeit, ed. Albrecht Koschorke, 221-239. Stuttgart: Metzler.

Wall, Barbara. 1991. The Narrator's Voice: The Dilemma of Children's Fiction. Basingstoke: Macmillan.

Open Access This chapter is licensed under the terms of the Creative Commons Attribution 4.0 International License (http://creativecommons.org/licenses/ by $/ 4.0 /$ ), which permits use, sharing, adaptation, distribution and reproduction in any medium or format, as long as you give appropriate credit to the original author(s) and the source, provide a link to the Creative Commons licence and indicate if changes were made.

The images or other third party material in this chapter are included in the chapter's Creative Commons licence, unless indicated otherwise in a credit line to the material. If material is not included in the chapter's Creative Commons licence and your intended use is not permitted by statutory regulation or exceeds the permitted use, you will need to obtain permission directly from the copyright holder.

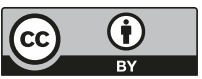

